\title{
Diabetes induces apoptosis in lymphocytes
}

\author{
R Otton ${ }^{1,2}$, F G Soriano ${ }^{3}$, R Verlengia ${ }^{1,4}$ and $\mathrm{R}$ Curi $^{1}$ \\ ${ }^{1}$ Department of Physiology and Biophysics, Institute of Biomedical Sciences, University of São Paulo, Av. Prof. Lineu Prestes, 1524, 05508-900, Butantan, \\ São Paulo, SP, Brazil \\ ${ }^{2}$ Cruzeiro do Sul University, Biological Sciences and Health Center, São Miguel Paulista, São Paulo, SP, Brazil \\ ${ }^{3}$ Department of Medical Clinic, LIM 51, Medicine School, University Hospital, University of São Paulo, SP, Brazil \\ ${ }^{4}$ Methodist University of Piracicaba, Faculty of Health of Science, Physical Education, São Paulo, SP, Brazil \\ (Requests for offprints should be addressed to R Otton, Department of Physiology and Biophysics, Institute of Biomedical Sciences, University of São Paulo; \\ Email: rose@fisio.icb.usp.br)
}

\begin{abstract}
The occurrence of DNA fragmentation in lymphocytes obtained from alloxan-induced diabetic rats and diabetic patients was investigated. A high proportion of apoptotic lymphocytes in diabetic states may explain the impaired immune function in poorly controlled diabetic patients. Rat mesenteric lymph node lymphocytes were analysed for DNA fragmentation by using flow cytometry and agarose gel, and for chromatin condensation by Hoescht 33342 staining under different situations. Immediately after being obtained, the proportion of lymphocytes with fragmented DNA was twofold higher in alloxan-induced diabetic rats than in cells from control rats. After $48 \mathrm{~h}$ in culture, the occurrence of DNA fragmentation was also higher $(81 \%)$ in cells from diabetic rats. Hoescht staining and fragmented DNA visualized in agarose gel were also
\end{abstract}

higher in lymphocytes from alloxan-induced diabetic rats than in control cells. To investigate if this phenomenon also occurs in humans, blood lymphocytes from 14 diabetic subjects were examined. Similar results to those of rat lymphocytes were found in cells from diabetic patients immediately after being obtained and after $48 \mathrm{~h}$ in culture. The high occurrence of apoptosis in lymphocytes was accompanied by a reduced number of blood-circulating lymphocytes in diabetic patients. The involvement of low insulinaemia for the occurrence of apoptosis in lymphocytes was also examined. Insulin treatment markedly reduced the proportion of lymphocytes with fragmented DNA in alloxan-induced diabetic rats.

Journal of Endocrinology (2004) 182, 145-156

\section{Introduction}

Apoptosis is an active form of cellular self-destruction that plays an essential role in tissue homeostasis, in embryonic development, and in the control of immune responses in the adult (Holmstrom \& Eriksson 2000, Rathmel \& Thompson 2002). However, apoptosis has a dark side: if it is turned on at the wrong time, crucial cells may die off. This suicide programme was originally defined by the morphology of dying cells (Kerr et al. 1972, Wyllie 1980). It is characterized by an ordered series of events that takes place over a period of time (Kidd 1998, Vermes et al. 2000). The length of time required for cells to undergo death is usually defined by the stimuli that trigger apoptosis (e.g. glucocorticoid, Fas ligand, growth factor withdrawal), and varies with the cell type (Wyllie 1984, Trauth et al. 1989, Koyama et al. 2000).

Apoptotic cells often shrink and undergo cytoplasmic membrane blebbing, their chromosomes rapidly condense and aggregate around the nuclear periphery, and small apoptotic bodies are formed (Wyllie 1980, Vermes et al. 2000, Eizirik \& Mandrup-Poulsen 2001). In many, but not all, apoptotic cells, the condensed chromosomes are acted upon by specific nucleases that cleave the DNA to produce a characteristic ladder (Wyllie 1980, Williams et al. 1990, Liu et al. 1998).

Lymphocyte apoptosis plays an important role in proper immune function (Porter \& Malek 1999). It removes developing lymphocytes that fail to express an antigen receptor; thereby ensuring a functional repertoire of mature $\mathrm{B}$ and $\mathrm{T}$ cells, and it maintains tolerance toward self by eliminating lymphocytes with antigen receptors that recognize autoantigens. Apoptosis also regulates the size and duration of immune responses. Activated lymphocytes are killed when an infection is cleared successfully (Newton \& Strasser 2001). However, when apoptosis malfunctions, the results may be dire and stroke damage in the organism can occur.

The occurrence of DNA fragmentation in lymphocytes obtained from alloxan-induced $(40 \mathrm{mg} / \mathrm{kg})$ diabetic rats was investigated. Rat mesenteric lymph node lymphocytes were analysed for DNA fragmentation using flow cytometry and agarose gel. Hoescht 33342 staining was used to evaluate chromatin condensation. The effect of insulin 
treatment in vivo and in vitro on prevention of apoptosis in lymphocytes from alloxan-induced diabetic rats was also examined. The occurrence of apoptosis was also evaluated in blood lymphocytes from poorly controlled diabetic subjects using DNA fragmentation assay. As additional evidence for the prevalence of apoptosis, the expression of pro- (c-myc, p53, and bcl-xS) and anti-apoptotic (bcl-2) genes was evaluated by RT-PCR in lymphocytes from one healthy and one diabetic acidotic subjects.

\section{Materials and Methods}

\section{Reagents and enzymes}

All reagents for buffers, alloxan monohydrate, sodium orthovanadate, propidium iodide, ethidium bromide, NADP and Triton X-100 were obtained from Sigma Chemical Company (St Louis, MO, USA). LymphoPrep was purchased from Nycomed Pharma AS (Oslo, Norway). Taq DNA polymerase, random primers and dNTP were purchased from Amersham Pharmacia (Buckinghamshire, UK). Hoechst 33342 was obtained from Molecular Probes (Eugene, OR, USA). RPMI-1640 culture medium, antibiotics, SuperScript II, and primers for bcl-2, bcl-xS, c-myc, p53 and GAPDH were purchased from InVitrogen (Grand Island, NY, USA).

\section{Animals}

Wistar male rats, weighing $220 \pm 20 \mathrm{~g}$, were obtained from the Department of Physiology and Biophysics, Institute of Biomedical Sciences, University of São Paulo. Animals were supplied with food and water and allowed to feed ad libitum, and were maintained in a room at $23^{\circ} \mathrm{C}$ with lights on from 0700 to $1900 \mathrm{~h}$. The Animal Experimental Committee of the Institute of Biomedical Sciences, University of São Paulo granted ethical approval for this study.

\section{Induction of diabetes}

The rats were either untreated (control group injected with saline $0.9 \% \mathrm{NaCl}$ ) or intravenously injected with alloxan (dissolved in saline solution, $\mathrm{pH}$ 7) at a dose of $40 \mathrm{mg} / \mathrm{kg}$ body weight, after an overnight fasting period as previously described (Otton et al. 2002a). Alloxan is a potent generator of reactive oxygen species, which can mediate $\beta$-cell toxicity (Cheng \& Roth 1971, Elsner et al. 2002). We chose the model of alloxan-induced diabetes because alloxan-diabetic rats present low plasma levels of insulin with no change in the activation state of the immune cells. The diabetic rats used in this study were those with glycaemia over $200 \mathrm{mg} / \mathrm{dl}$, after 7 days of alloxan injection.

\section{Insulin treatment}

A group of diabetic rats was treated with neutral protamine hagedorn $(\mathrm{NPH})$ insulin through s.c. administration of $1 \mathrm{U}$ per rat for 3 days. The addition of insulin at a dose of $1 \mathrm{mU} / 10^{7}$ cells was also performed on lymphocytes from alloxan-induced diabetic rats in culture. Lymphocytes were analysed by flow cytometry immediately after being obtained and after $48 \mathrm{~h}$ in culture. A similar procedure has been used in our previous study (Otton et al. 2002a,b).

\section{Experimental procedure}

Diabetic rats and matching controls were kept under similar conditions. After 7 days of diabetes induction, fed rats were killed by decapitation without anaesthesia between 0800 and $1100 \mathrm{~h}$. Mesenteric lymph nodes were dissected and lymphocytes were prepared as previously described (Curi et al. 1988). After centrifugation at $1200 \mathrm{~g}$ for $10 \mathrm{~min}$, lymphocytes were suspended in RPMI-1640 medium and then cultured. In all experiments at least seven animals were used per group and at least three different experiments were carried out for each analysis. The blood glucose levels of non-fasted rats were examined through glucose-oxidase assay (Trinder 1969) following the manufacturer's instructions (Glucose E assay Kit from Merck, Rio de Janeiro, Brazil). Glycaemia of the diabetic group was $582 \pm 13 \mathrm{mg} / \mathrm{dl}$ and that of the control group was $99 \pm 5 \mathrm{mg} / \mathrm{dl}$ (mean \pm s.E.M. of seven animals).

The number of viable cells $(>95 \%)$ was determined in a Neubauer chamber using an optical microscope (Nikon YS2-H), following addition of Trypan Blue aqueous solution $(1 \% \mathrm{w} / \mathrm{v})$. Non-viable cells were also evaluated in the flow cytometer FACScalibur (Becton Dickinson, Mountain View, CA, USA) by using propidium iodide as described below.

\section{Subjects}

Fourteen diabetic patients (11 males, 3 females), ages ranging from 13 to 82 years old, and 15 controls (10 males, 5 females), ages ranging from 21 to 43 years old, participated in the study. The Human Ethic Committee of the Institute of Biomedical Sciences and Faculty of Medicine, São Paulo University approved the research protocol of this study.

The patients used in this study were those treated in the Hospital of the São Paulo University. The blood glucose levels were determined by the glucose-oxidase method following the manufacturer's instructions (Glucose E assay Kit from Merck). The blood glucose levels of the patients used were above $200 \mathrm{mg} / \mathrm{dl}$ in a non-fasted condition (Table 1).

\section{Blood samples}

Peripheral human blood lymphocytes were collected by a venepuncture procedure and placed in vacuum/ siliconized test tubes containing heparin anticoagulant agent. Blood samples were diluted in $150 \mathrm{mM} \mathrm{NaCl}$ 
Table 1 Characteristics of the diabetic patients

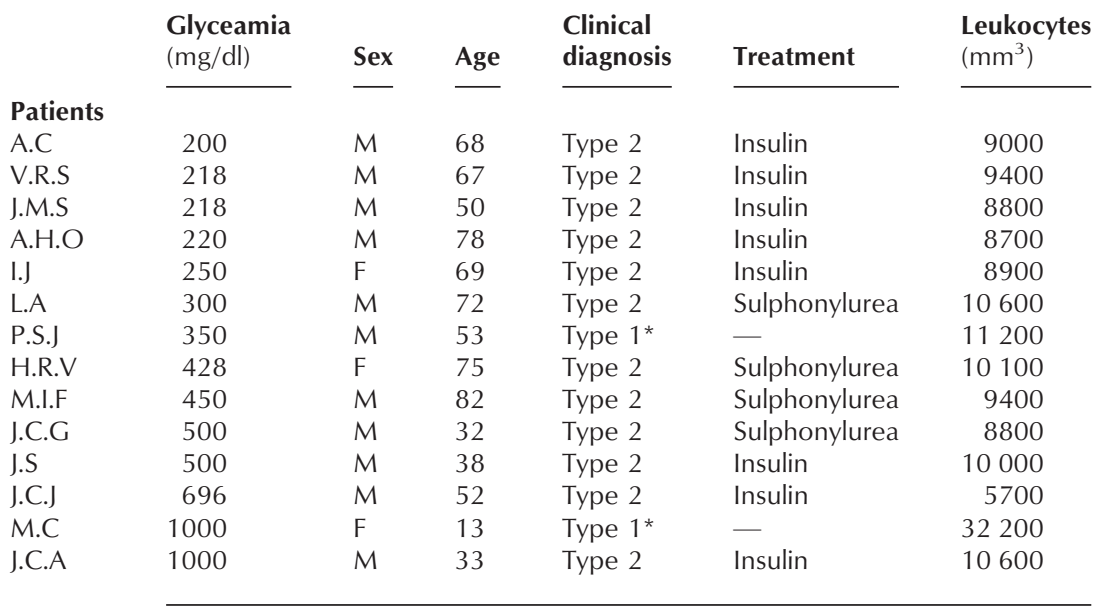

Type 2 diabetes mellitus.

*Type 1 diabetes mellitus diagnosed as the first event of cetosis.

solution and lymphocytes were separated using LymphoPrep (Nycomed) according to manufacturer's instructions. Cells were analysed by flow cytometry immediately after being obtained or after being cultured for 12, 24 and $48 \mathrm{~h}$ when indicated. Non-viable cells were identified by using propidium iodide $(50 \mu \mathrm{g} / \mathrm{ml})$ dissolved in PBS $(0 \cdot 137 \mathrm{M}$ $\mathrm{NaCl}, 2 \cdot 7 \mathrm{mM} \mathrm{KCl}, 8 \cdot 0 \mathrm{mM} \mathrm{Na} \mathrm{HPO}_{4}$, pH 7.4). Propidium iodide fluorescence was determined in Filter length (FL2) $(580 \mathrm{~nm})$ using a FACScalibur cytometer (Becton Dickinson). Propidium iodide is a highly watersoluble fluorescent compound that cannot pass through intact membranes and is generally excluded from viable cells. It binds to DNA by intercalating between the bases with little or no sequence preference. An increase in fluorescence to propidium iodide indicates a decrease in the proportion of viable cells.

\section{Cell culture conditions and treatment with concanavalin $A$ (Con A) and lipopolysaccharide (LPS)}

A similar culture procedure was used for lymphocytes from human and rats. Lymphocytes $\left(5 \times 10^{5}\right.$ cells/well $)$ were obtained as described earlier and re-suspended in RPMI1640 medium supplemented with 10\% foetal calf serum, containing $5.6 \mathrm{mM}$ glucose, $2 \mathrm{mM}$ glutamine, and antibiotics (streptomycin 100 units $/ \mathrm{ml}$ and penicillin 200 units $/ \mathrm{ml}$ ). Lymphocytes were cultured in 96-well microtitre plates at $37^{\circ} \mathrm{C}$ in an air- $\mathrm{CO}_{2}(95 \%-5 \%)$ atmosphere. After culturing for 12, 24 and $48 \mathrm{~h}$, cells were collected and used for flow cytometric analysis.

The rate of DNA fragmentation in human lymphocytes was evaluated in the absence of stimulus. In rat lymphocytes, DNA fragmentation was evaluated after culturing for 12, 24 and $48 \mathrm{~h}$ in the absence and in the presence of Con A $(20 \mu \mathrm{g} / \mathrm{ml})$ or LPS $(100 \mu \mathrm{g} / \mathrm{ml})$ when indicated.
Con $\mathrm{A}$ is a well known mitogen for $\mathrm{T}$ lymphocytes (Licastro et al. 1993), whereas LPS stimulates B-lymphocyte proliferation (Antal-Szalmas 2000). This experiment was performed to investigate the response of cells to an immune challenge.

\section{Analysis of DNA fragmentation by flow cytometry}

Rat and human lymphocytes cultured as described above were collected, centrifuged at $1200 \boldsymbol{g}$ for $10 \mathrm{~min}$ and re-suspended in a hypotonic solution containing propidium iodide $50 \mu \mathrm{g} / \mathrm{ml}$ in $0 \cdot 1 \%$ citrate plus $0 \cdot 1 \%$ Triton $\mathrm{X}-100$ and maintained at $4{ }^{\circ} \mathrm{C}$ in darkness overnight (Nicoletti et al. 1991). Analyses to detect apoptotic cells were performed in a FACScalibur cytometer equipped with CellQuest software (Becton Dickinson). A decrease in fluorescence to propidium iodide indicates a decrease in DNA content in lymphocytes. Cell size and granularity were monitored by alterations in forward scatter and side scatter respectively. The forward scatter light is a result of diffraction of the laser beam when it reaches the cell. Diffracted light provides basic morphological information, such as relative cell size. Light that is scattered at $90^{\circ}$ to the incident beam is the result of refracted and reflected light and is called side scatter. This parameter is an indicator of granularity within the cytoplasm of cells, as well as surface/membrane irregularities or topographies. The DNA fragmentation was observed by the occurrence of low fluorescent particles. This indicates that DNA was cleaved and there are small DNA fragments that, because of their high condensation and small size, cannot be intensively bound by propidium iodide, and are seen as low fluorescent particles. The graphics presented in Figs 1 and 4 were made using the percentages obtained in 
Table 2 The standardized conditions for RT-PCR analysis. The sequences of the primers, the PCR fragment lengths, the temperature and the number of cycles are shown for each gene under study. For bcl-xS, c-myc, p53 and GAPDH genes, $\mathrm{MgCl}_{2}$ was used at $1.5 \mathrm{mM}$, whereas for the bcl-2 gene, $2 \cdot 0 \mathrm{mM}$ was employed

\section{Sense primer}

\section{Genes}

bcl-2

bcl-xS

c-myc

p53

GAPDH

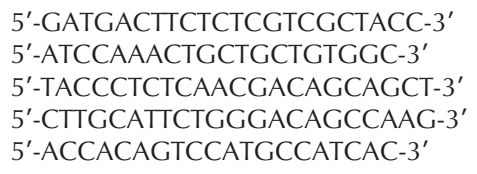

\section{Antisense primer}

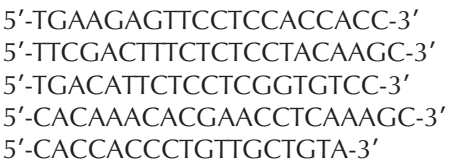

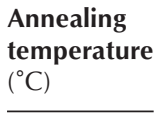

60

59

60

60

60

PCR fragment
lengths
(bp)

110

201

455

594

452
Number of cycles

35

30

45

33

30 histogram plots of propidium iodide fluorescence intensity. The instrument settings were the same for all experiments.

\section{DNA fragmentation analysed by agarose gel electrophoresis}

Inter-nucleosomal DNA fragmentation was analysed in lymphocytes from diabetic and control rats by agarose gel electrophoresis. Cells that were cultured $\left(2 \times 10^{6}\right)$ for $24 \mathrm{~h}$ in RPMI-1640 medium without treatment were collected and pelleted by centrifugation at $1200 \mathrm{~g}$ for $10 \mathrm{~min}$. Whole cells were prepared for in-gel digestion and DNA was separated on a $2 \%$ agarose gel together with a $100 \mathrm{bp}$ ladder marker (Otha et al. 1995). DNA was visualized under u.v. light after being stained with ethidium bromide $(0.5 \mu \mathrm{g} / \mathrm{ml})$ and photographed.

\section{Chromatin condensation assay}

Morphology of lymphocytes was examined immediately after being obtained and after 24 and $48 \mathrm{~h}$ of culture. Cells $\left(1 \times 10^{6}\right)$ were suspended in $20 \mu \mathrm{l} 0.9 \% \mathrm{NaCl}$ solution containing $0.01 \mathrm{mg} / \mathrm{ml}$ Hoescht 33342. After $10 \mathrm{~min}$, the cells were observed in a fluorescence microscope (Axiovert 100, Zeiss) under u.v. light $(365 / 380 \mathrm{~nm})$. Images were analysed using the Axio Vision software (Zeiss). Intensity of fluorescence was calculated using the KS300 3.0 Image System software (Zeiss).

\section{Total RNA extraction}

Total RNA was extracted from lymphocytes $(0 \cdot 5-1$ $\times 10^{7}$ ) obtained from one diabetic and one control subjects using Trizol reagent (InVitrogen, Rockville, MD, USA). Briefly, the cells were lysed using $1 \mathrm{ml}$ Trizol reagent. After a 5-min incubation at room temperature, $200 \mu \mathrm{l}$ chloroform was added to the tubes and centrifuged at $12000 \mathrm{~g}$. The aqueous phase was transferred to another tube and the RNA was pelleted by centrifugation $(12000 \mathrm{~g})$ with cold ethanol and dried in air. RNA pellets were eluated in RNase-free water and stored at $-70{ }^{\circ} \mathrm{C}$ until the time of the experiment. The RNA was quanti- fied by measuring absorbance at $260 \mathrm{~nm}$. The purity of the RNA preparations was assessed by the $260 / 280 \mathrm{~nm}$ ratios and on a $1 \%$ agarose gel stained with ethidium bromide at $5 \mu \mathrm{g} / \mathrm{ml}$ (Sambrook \& Russell 2001). These samples were used for RT-PCR analysis.

\section{RT-PCR}

Total RNA $(2 \mu \mathrm{g})$ was treated with 1 U DNase for $25 \mathrm{~min}$ at $25{ }^{\circ} \mathrm{C}$ and inactivated with $2.5 \mathrm{mM}$ EDTA. Afterwards, the cDNA was synthesized using oligo (dT) in a $20 \mu \mathrm{l}$ reaction containing $1 \mathrm{mM}$ of each dNTP, $10 \mathrm{mM}$ DTT, and $200 \mathrm{U}$ SuperScript II RNase $\mathrm{H}^{-}$reverse transcriptase at $42{ }^{\circ} \mathrm{C}$ for $50 \mathrm{~min}$ according to the manufacturer's instructions. Heating at $70{ }^{\circ} \mathrm{C}$ for $15 \mathrm{~min}$ inactivated the reaction.

The PCR reaction was performed in a total volume of $25 \mu \mathrm{l}$, containing $2.5 \mu \mathrm{l}$ of buffer DNA polymerase enzyme $\left(50 \mathrm{~mm} \mathrm{KCl}, 1.5 \mathrm{mM} \mathrm{MgCl}_{2}, 10 \mathrm{mM}\right.$ Tris- $\mathrm{HCl}$, $\mathrm{pH} 9 \cdot 0), 10 \mathrm{pmol}$ of the primer, $200 \mu \mathrm{M}$ of each nucleotide (dATP, dCTP, dGTP and dTTP) and $2.5 \mathrm{U}$ of Taq DNA polymerase and $2 \mu \mathrm{l}$ of cDNA. The RT and PCR reactions were carried out in a Techne Touchgene Gradient equipment (model FTGRAD2SD, Cambridge, UK), using parameters described by Innis \& Gelfand (1990). The number of cycles used was selected to allow quantitative comparison of the samples in a linear way. For semi-quantitative PCR analysis, the housekeeping GAPDH gene was used as reference. Published guidelines were followed to guard against bacterial and nucleic acid contamination (Kwok \& Higuchi 1989).

\section{Primers used}

The sequences of the primers were designed using information contained in the public database in the GenBank of the National Center for Biotechnology Information (NCBI). The sequence of primers for the c-myc gene was the same as that used by Hsieh et al. (1997). The 
sequences, annealing temperature, number of cycles, and lengths of fragment formed used in this study are shown in Table 2.

\section{Analysis of the PCR products}

The analysis of PCR amplification products was performed in $1.5 \%$ agarose gels containing $0.5 \mu \mathrm{g} / \mathrm{ml}$ ethidium bromide and electrophoresed for $1 \mathrm{~h}$ at $100 \mathrm{~V}$. The gels were photographed using a DC120 Zoom Digital Camera System from Kodak (InVitrogen, Rockville, MD, USA). The images were processed and analysed in the software Kodak Digital Science 1D Image Analysis.

PCR band intensities were expressed as OD normalized for glyceraldehyde 3-phosphate dehydrogenase (GAPDH) expression. The data are presented as the ratio with the respective controls, which received an arbitrary value of 1 in each experiment.

\section{Protein content determination}

Protein content of cell homogenates was measured by the method of Bradford (Bradford 1976), using BSA as standard.

\section{Statistical analysis}

The results were expressed as mean and S.E.M. for 15 wells of at least three experiments, as indicated in the figures. ANOVA was employed to detect differences between the groups. $P<0 \cdot 05$ was taken to indicate significant differences.

\section{Results}

DNA fragmentation in lymphocytes from diabetic rats

Fluorescence-activated cell sorter (FACS) analysis DNA fragmentation was evaluated in freshly obtained lymphocytes from control and alloxan-induced diabetic rats, and in cells cultured for 12, 24 and $48 \mathrm{~h}$ without treatment (Fig. 1A) and after being stimulated with Con A or LPS (Fig. 1B and C respectively). Cells from diabetic rats presented at the beginning of the culture period a higher proportion of cells in apoptosis $(2 \cdot 2$-fold) as compared with the control group (Fig. 1A). The proportion of lymphocytes with fragmented DNA from both control and diabetic rats was increased during the culture period. The percentage of lymphocytes with fragmented DNA after $48 \mathrm{~h}$ in culture was higher (81\%) in untreated lymphocytes from diabetic rats as compared with untreated cells from the control group.

Con A stimulation enhanced proliferation of lymphocytes from controls by 40-fold, whereas LPS stimulation raised it by threefold. In the diabetic group this stimulation was slightly; Con A by 25 -fold and LPS by 1.5-fold. Treatment with Con A (Fig. 1B) and LPS (Fig.
A

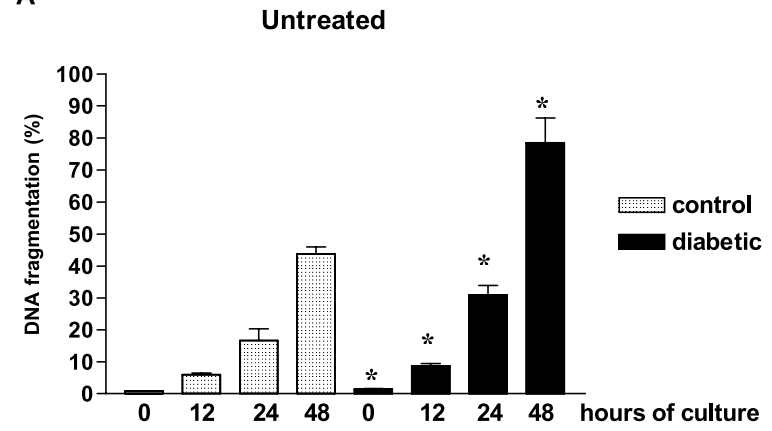

B Con Atreatment

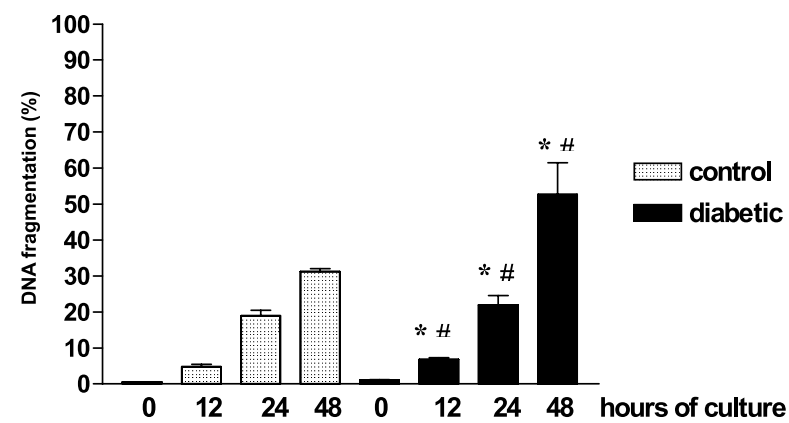

C LPS treatment

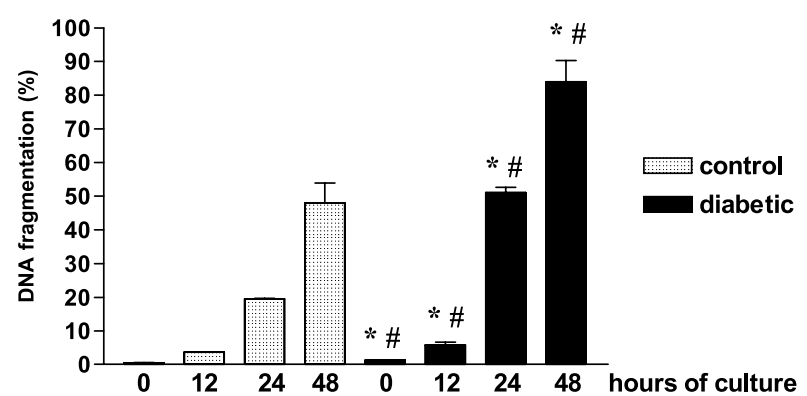

Figure 1 Effect of alloxan-induced diabetes on DNA fragmentation of rat lymphocytes. Cells obtained from control and diabetic rats were analysed by flow cytometry using propidium iodide (FL2) as described in the Materials and Methods section. DNA fragmentation was analysed in lymphocytes cultured without treatment (A) or after treatment with $5 \mu \mathrm{g} / \mathrm{ml}$ of Con A (B) and $100 \mu \mathrm{g} / \mathrm{ml}$ of LPS (C) for 12,24 and $48 \mathrm{~h}$ in culture. The results are presented as means \pm S.E.M. from 15 wells of three different experiments using 10 rats each. ${ }^{*} P<0 \cdot 05$, as compared with the control group at the corresponding time; $\# P<0 \cdot 05$, as compared with untreated lymphocytes at the corresponding time.

1C) affected the occurrence of apoptosis in lymphocytes. Con A treatment reduced the occurrence of apoptosis in lymphocytes from diabetic rats as compared with untreated cells. LPS stimulation in turn increased DNA fragmentation in lymphocytes from diabetic rats. 

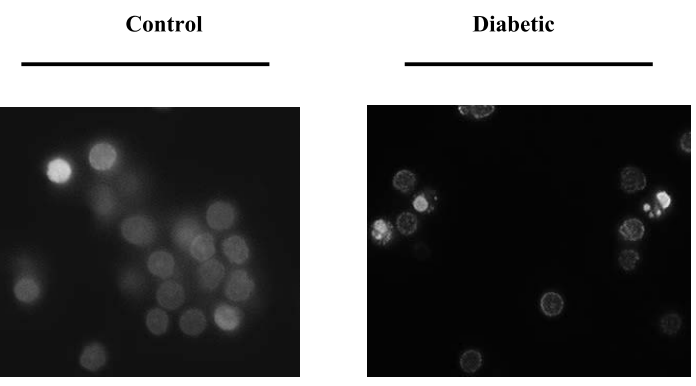

$24 \mathrm{~h}$
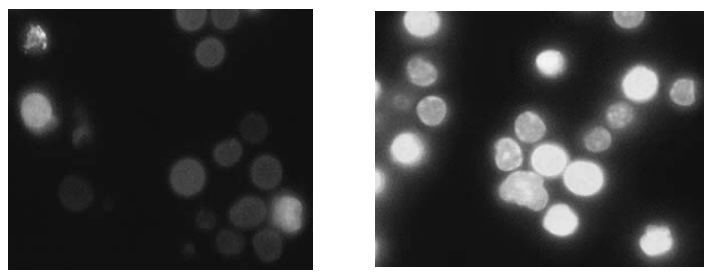

$48 \mathrm{~h}$
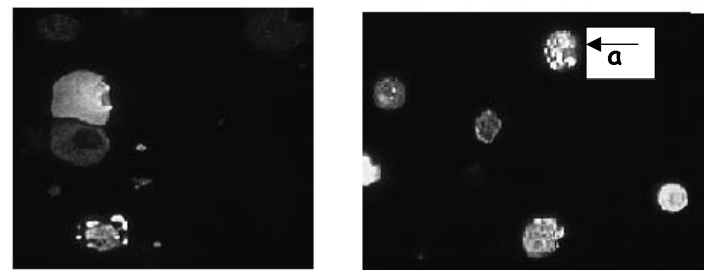

Figure 2 Morphology of the nuclei of lymphocytes from alloxan-induced diabetic and control rats. Cells were harvested immediately after being obtained $(0 \mathrm{~h})$ and after 24 and $48 \mathrm{~h}$ of culture, and stained with Hoescht 33342 as described in the Materials and Methods section. "a" indicates the presence of blebbing.

Chromatin condensation assay To examine the effect of diabetes on nucleus chromatin condensation, rat lymphocytes $\left(5 \times 10^{5}\right)$ were stained with Hoescht 33342 that is actively taken up by vital cells and shows blue fluorescence. Condensation of nuclear chromatin is characterized by loss of the structural framework resulting in a smooth, homogeneous appearance and DNA hyperchromicity that, combined with nuclear fragmentation, is the most characteristic feature of apoptosis. Immediately after being obtained $(0 \mathrm{~h})$, the number of lymphocytes with nuclei presenting condensed chromatin was higher in the diabetic group (Fig. 2A). After 24 and $48 \mathrm{~h}$ of culture, there was an increase in the proportion of cells from diabetic as compared with control rats showing chromatin condensation, apoptotic bodies and fragmentation of the nucleus (Fig. 2B,C).

Agarose gel electrophoresis analysis The chromosomal DNA fragmentation into oligonucleosomal-sized DNA is another indicator of the occurrence of apoptosis (Vermes et al. 2000). After $24 \mathrm{~h}$ of culture, the occurrence of fragmented DNA was higher in lymphocytes from diabetic rats than in cells from the control group (Fig. 3).

\section{MW control diabetic}

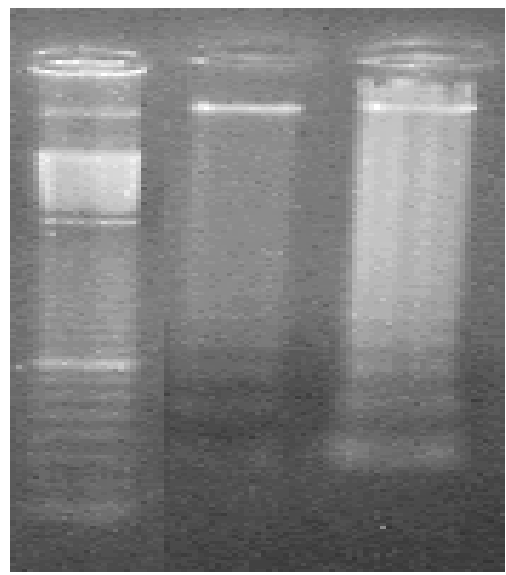

Figure 3 Effect of alloxan-induced diabetes on internucleosomal DNA fragmentation in rat lymphocytes. After $24 \mathrm{~h}$ of culture, cells were harvested and DNA was extracted, and analysed in $2 \%$ agarose gel as described in the Materials and Methods section (MW = molecular weight). The results presented are representative of three different experiments using five rats each.

Insulin treatment In lymphocytes obtained from alloxan-induced diabetic rats after in vivo insulin treatment, DNA fragmentation was similar between lymphocytes from control and insulin-treated diabetic rats (Fig. 4).

In another experiment, lymphocytes were isolated from diabetic rats and cultured in the presence of insulin for $48 \mathrm{~h}$ as described in Materials and Methods. Under this in vitro condition, insulin treatment was not able to reduce the number of apoptotic lymphocytes (data not shown).

DNA fragmentation in lymphocytes from diabetic patients The effect of diabetes upon DNA fragmentation in blood human lymphocytes was evaluated by flow cytometry before culturing and after $48 \mathrm{~h}$ in culture (Fig. $5 A)$. Results show that immediately after being obtained the percentage of lymphocytes with fragmented DNA was twofold higher in diabetic patients compared with cells from healthy individuals. The proportion of lymphocytes with fragmented DNA remained higher $(2 \cdot 5$-fold $)$ in diabetic patients even after $48 \mathrm{~h}$ of culture.

Flow cytometric analysis of lymphocytes from diabetic patients showed two distinct populations of cells on a forward scatter (a measure of cell size) versus side scatter (a measure of cell granularity) dot plot. Before culturing, one population of lymphocytes from diabetic patients had a normal cell size, similar to control cells, while a second population had a smaller or shrunken cell size, characteristic of apoptosis (Fig. 5B, $0 \mathrm{~h}$ ). After $48 \mathrm{~h}$ in culture, a significant proportion of lymphocytes from diabetic patients showed reduced volume and an increased granularity as compared with cells from control subjects 


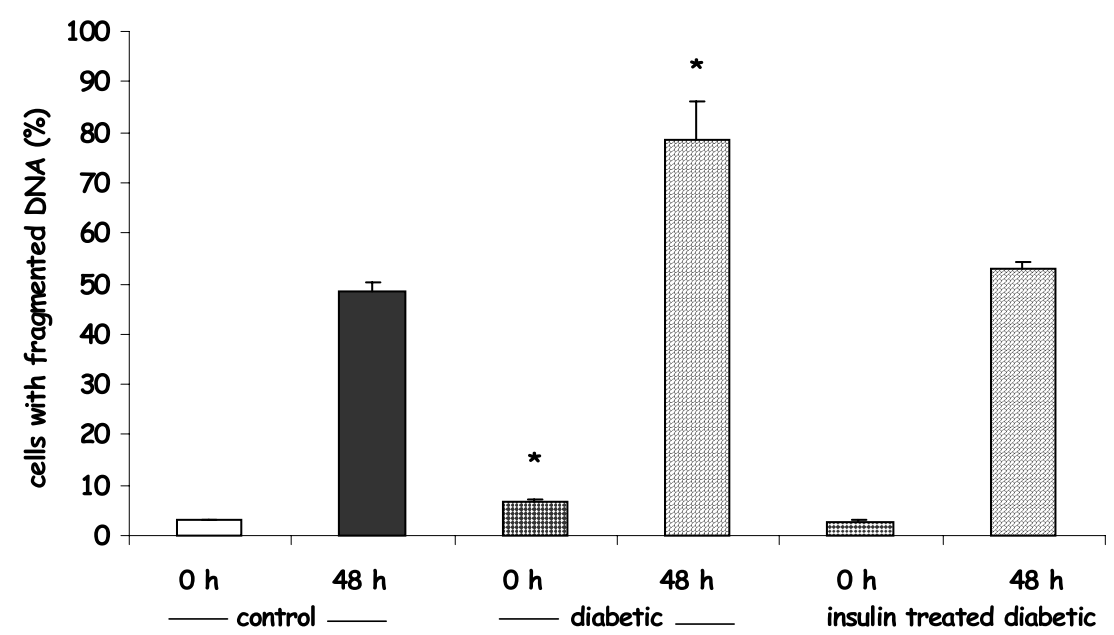

Figure 4 Effect of insulin treatment upon DNA fragmentation of rat lymphocytes. Cells were obtained from control, diabetic and insulin-treated diabetic rats. Cells were analysed by flow cytometry using propidium iodide (FL2) as described in the Materials and Methods section immediately after being obtained $(0 \mathrm{~h})$ and after $48 \mathrm{~h}$ of culture. The results are presented as means + S.E.M. of 15 determinations from two experiments using three rats each. ${ }^{*} P<0.05$ compared with the control group.

(Fig. 5B, $48 \mathrm{~h}$ ). The representative DNA content of lymphocytes from diabetic and control subjects after $48 \mathrm{~h}$ of culture is shown in a histogram plot graph.

In our study the absolute number of leukocytes was increased in diabetic patients (mean of $10958 \pm 6257$ cells/ $\mu$ l of blood; mean \pm S.E.M. of 14 patients) as compared with control subjects (mean of $7114 \pm 1523$ cells $/ \mu 1$ of blood; mean \pm s.E.M. of 10 control subjects). However, the absolute number of lymphocytes was significantly decreased (mean of $1468 \pm 561$ cells/ $\mu$ l of blood; mean \pm S.E.M. of 14 patients) in diabetic compared with control subjects (mean of $2436 \pm 256$ cells/ $\mu$ l of blood; mean \pm S.E.M. of 10 control subjects).

Diabetic patients with normal glycaemia, regardless their age, did not show changes in the proportion of lymphocytes in apoptosis as compared with control subjects. For example, one 70-year-old patient who was diabetic for 35 years but with well-controlled glycaemia by insulin treatment did not show an increase in the proportion of lymphocytes in apoptosis (data not shown).

Expression of anti- and pro-apoptotic genes As additional evidence for the occurrence of apoptosis, a molecular approach was carried out in circulating lymphocytes from one diabetic (acidotic) and one control patient. The RT-PCR measurements of pro- and antiapoptotic genes were performed three times. Marked differences were observed in the expression of bcl-2, bcl-xS, c-myc and p53 in lymphocytes obtained from the diabetic patient as compared with cells from a healthy subject. The expression of the anti-apoptotic gene bcl-2 was decreased by $85 \%$, whereas that of the pro-apoptotic genes bcl-xS (25\%), c-myc (twofold) and p53 (38\%) was increased in lymphocytes from the untreated diabetic patient compared with cells from the control subject (Fig. 6).

\section{Discussion}

Lymphocytes are subject to death checkpoints during their lifespan to ensure proper development, maintain homeostasis, and prevent diseases (Rathmel \& Thompson 2002). Activation, clonal expansion and cell death form the basis for the generation of a repertoire of immunocompetent cells that allows the immune system to eliminate foreign antigens while respecting self structures (Janssen et al. 2000). In the periphery, lymphocyte numbers are tightly regulated and, despite periodic expansion during immune responses, remain relatively constant in mature animals. This is accomplished by balancing production of newly matured cells in bone marrow and thymus and peripheral lymphocyte expansion with cell death (Tough \& Sprent 1995). Enhanced lymphocyte apoptosis can cause immunodeficiency, whereas cancer and autoimmune diseases can occur when there is too little apoptosis (Miller \& Marx 1998).

A number of studies have shown that diabetic patients have leukocytosis (Eastman et al. 1991, Flood \& Chiang 2001, Lavabre-Bertrand et al. 2001, Maraschio et al. 2003). In the present study the number of leukocytes was increased but that of lymphocytes was decreased in diabetic patients. This might play an important role for the impaired immune function and high incidence of infections in poorly controlled diabetic patients (Pallavicini \& William 1976, Yokono et al. 1989). The decrease in the 
A

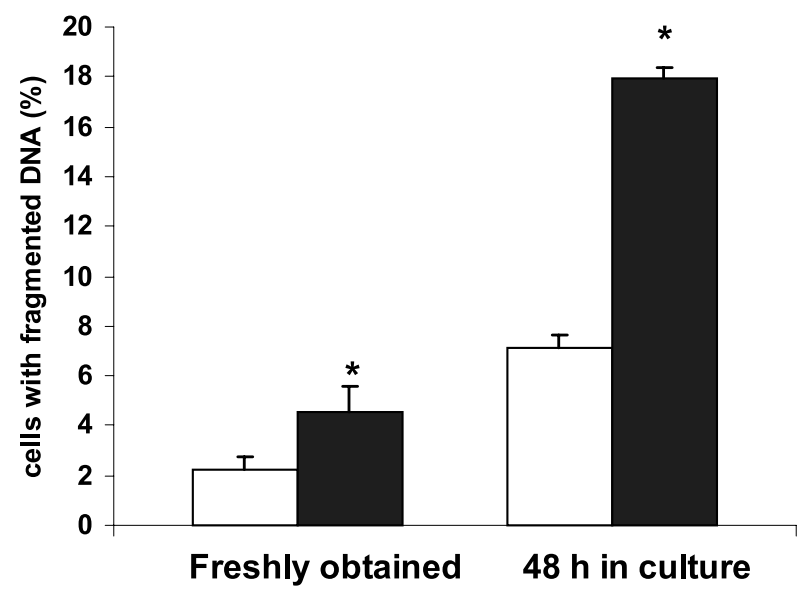

\section{$\square$ control \\ diabetic}

B
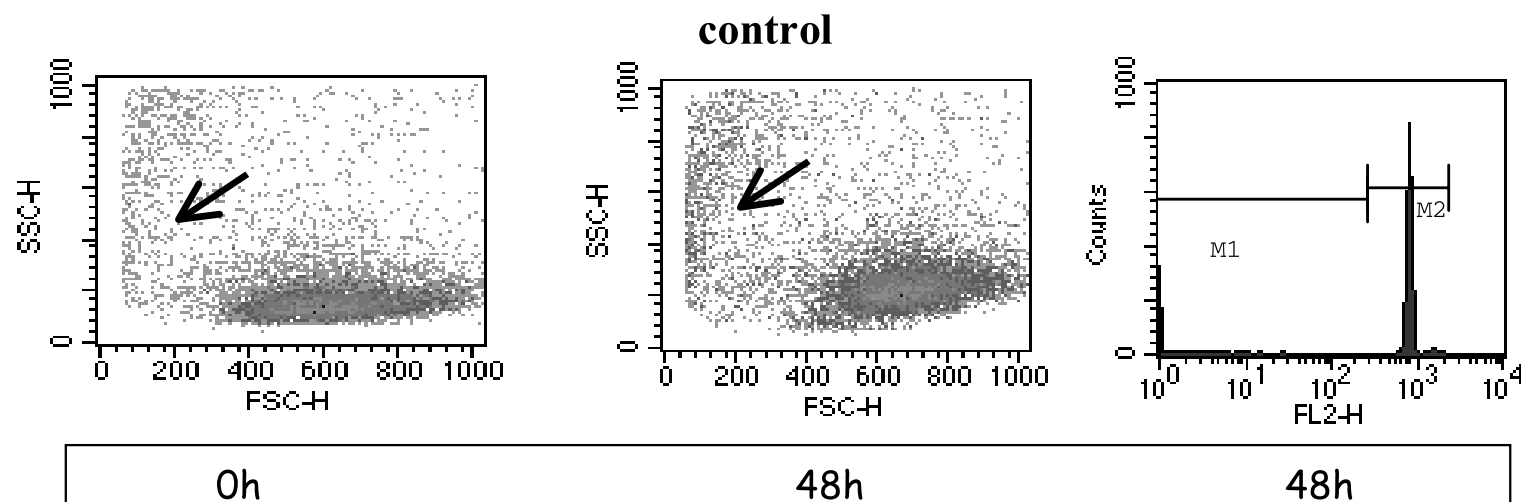

$48 \mathrm{~h}$

$48 \mathrm{~h}$

\section{diabetic}

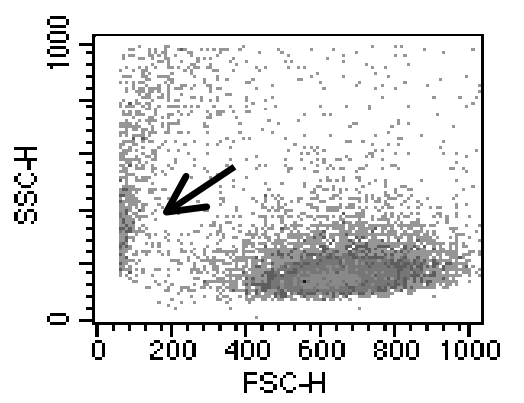

$\mathrm{Oh}$

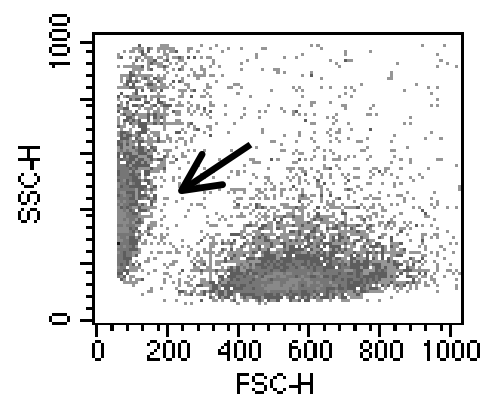

$48 \mathrm{~h}$

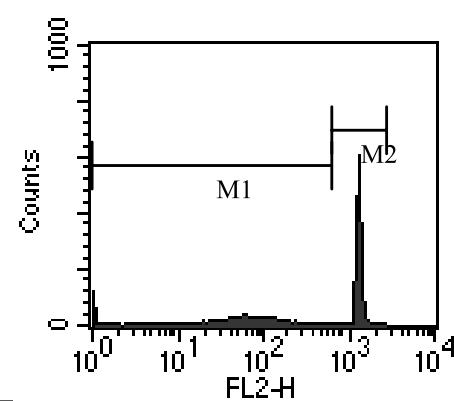

$48 h$

Figure 5 Occurrence of DNA fragmentation in human lymphocytes. Cells were analysed by flow cytometry using propidium iodide (FL2) as described in the Materials and Methods section. (A) DNA fragmentation was analysed in freshly obtained lymphocytes and after $48 \mathrm{~h}$ of culture. The results are presented as means+S.E.M. of five individual analyses of lymphocytes from 14 diabetic patients and 14 control subjects. ${ }^{*} P<0.05$ compared with the control group. (B) Forward scatter (FSC) and side scatter (SSC) of lymphocytes obtained from control healthy individuals and diabetic patients before and after $48 \mathrm{~h}$ of culture. Representative histogram plots of DNA content are show after a 48-h culture period. Arrows indicate apoptotic lymphocytes. $\mathrm{H}$, height; $\mathrm{M} 1$, marker 1 (apoptotic cells); M2, marker 2 (normal cells). 


\section{bcl-2}
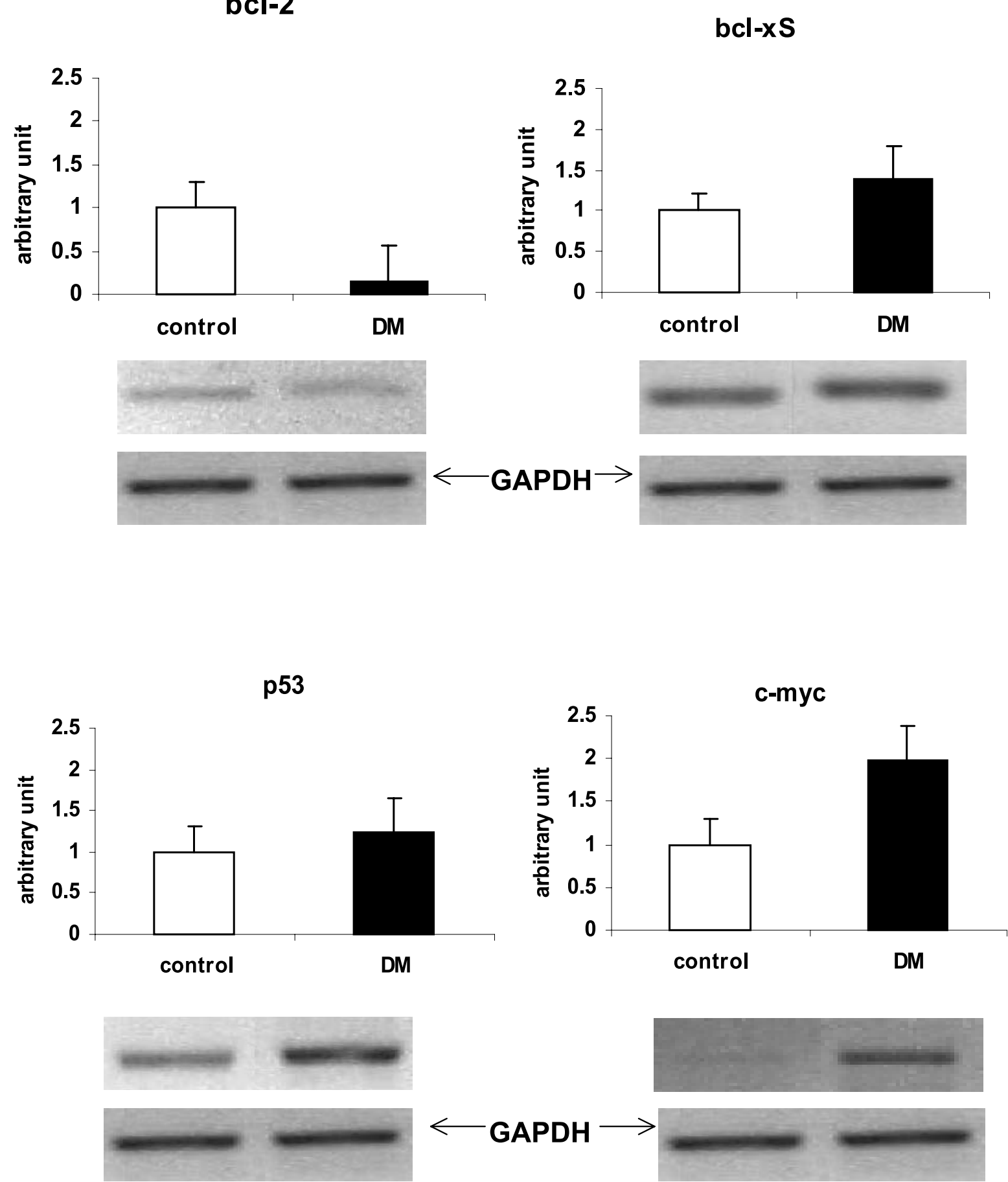

Figure 6 Evaluation by RT-PCR of the expression of the anti- (bcl-2) and pro-apoptotic (bcl-xS, p53 and c-myc) genes in human lymphocytes. Lymphocytes $\left(10^{7}\right.$ cells) from one control and one diabetic subject were harvested, total RNA extracted, and RT-PCR performed. PCR band intensities were expressed as OD normalized for GAPDH expression. Data are presented as the ratio with the respective controls, which received an arbitrary value of 1 in each experiment. Results are presented as means+S.E.M. of three experiments. 
number of lymphocytes is probably a clinical consequence of the occurrence of apoptosis described herein.

Several studies demonstrated a striking correlation between the overall prevalence of infection and the metabolic control in diabetes (Reinhold et al. 1996, Rayfield et al. 1982). A profound T lymphopenia proceeds to type 1 diabetes (Jackson et al. 1981, Yale et al. 1985). Peripheral T lymphocytes are not only reduced in number but also functionally impaired (Elder \& Maclaren 1992, Jung et al. 1999, Otton et al. 2002). Increased apoptosis in peripheral blood smear lymphocytes was found to be associated with diabetes, glucocorticoid administration and neoplastic diseases (Shidham \& Swami 2000).

In our study, blood peripheral lymphocytes obtained from poorly controlled diabetic patients presented increased DNA fragmentation as compared with cells obtained from healthy patients. Lymphocytes from alloxan-induced diabetic rats also showed increased DNA fragmentation when compared with cells from controls. Concomitantly, there was also high occurrence of chromatin condensation and blebbing formation. These observations strongly support the proposition that uncontrolled diabetes leads to lymphocyte death. The mechanisms for the differences in DNA fragmentation induced by Con A and LPS treatment on lymphocytes from diabetic rats remain to be investigated. The signalling pathways involved in the lymphocyte proliferation induced by the two mitogens are the main targets to be studied such as protein kinase C and toll-like receptor 4 (Lien \& Ingalls 2002).

Molecular indications for the occurrence of apoptosis in lymphocytes from one diabetic (acidotic) patient were also obtained. Mitochondria are potent integrators and coordinators of programmed cell death (Brenner \& Kroemer 2000). The integration phase of apoptosis is triggered in response to an induction phase that corresponds to a change in mitochondrial membrane permeability (MMP) (Belzacq et al. 2003). This change results, at least in part, from the opening of the permeability transition pore complex (PTPC), a mitochondrial multiprotein complex. This phase is controlled by oncogenes and anti-oncogenes of the bcl-2 family. Some pro-apoptotic proteins promote an increase in MMP and anti-apoptotic members stabilize the barrier function of mitochondrial membranes (Zoratti \& Szabo 1995). The expression of bcl-2, an anti-apoptotic member of the bcl-2 family, was significantly decreased in lymphocytes from the acidotic diabetic subject as compared with cells from the healthy patient. These finding in association with higher expression of pro-apoptotic genes c-myc, p53 and bcl-xS greatly corroborate with the proposition that uncontrolled diabetes leads lymphocytes to death by a mechanism that involves mitochondria and gene expression.

An enhanced susceptibility to infections is well known to occur in poorly controlled diabetic individuals (Kraine \& Tisch 1999). Abnormalities in the defence mechanisms of poorly controlled diabetic individuals against a variety of infectious agents have long been recognized (Pallavicini \& William 1976). The incidence of a recognized group of rare infections is definitely high or confined almost entirely to poorly controlled diabetic patients (Larkin et al. 1985). T-cell blastic transformation stimulated by phytohaemagglutin (Korfel et al. 1990) and plasma levels of immunoglobulins (Muller et al. 1989) are markedly reduced in untreated patients with diabetes mellitus type 1 , an effect reversed by insulin administration. In addition, in untreated diabetic mice, the secretion of IL-4 is markedly reduced, in contrast to the secretion of interleukin-2 (IL-2) and interferon- $\gamma$ (IFN- $\gamma$ ), which is not affected (Wood et al. 1999).

It is noteworthy that DNA fragmentation was markedly reduced after in vivo insulin treatment of alloxan-induced diabetic rats. The addition of insulin $\left(1 \mathrm{mU} / 10^{7}\right.$ cell $)$ to lymphocytes from alloxan-induced diabetic rats in culture for $48 \mathrm{~h}$ was not able to prevent the process of apoptosis (data not shown). The authors believe that once the machinery for apoptosis is triggered by the poorly controlled metabolic state induced by hypoinsulinaemia it can not be reverted by addition of insulin. So, the administration of insulin in vivo may prevent the start up of lymphocyte apoptosis.

The findings presented herein support the proposition that the high incidence of infection in poorly controlled diabetic states may be associated with an increased proportion of apoptotic lymphocytes.

\section{Acknowledgements}

The authors are indebted to the constant assistance of $\mathrm{G}$ de Souza, and Dr C K Miyasaka.

\section{Funding}

This research was supported by FAPESP, CNPq and PRONEX.

\section{References}

Antal-Szalmas P 2000 Evaluation of CD14 in host defense. European Journal of Clinical Investigation 30 167-179.

Belzacq AS, Vieira HL, Verrier F, Vandecasteele G, Cohen I, Prevost MC, Larquet E, Pariselli F, Petit PX, Kahn A et al. 2003. Bcl-2 and Bax modulate adenine nucleotide translocase activity. Cancer 15 541-546.

Bradford M 1976 A rapid and sensitive method for the quantification of microgram quantities of protein utilizing the principle of protein-dye binding. Analytical Biochemistry 72 248-254.

Brenner C, Kroemer G 2000 Apoptosis. Mitochondria - the death signal integrators. Science 18 1150-1151.

Cheng CC, Roth B 1971 Some pyrimidines of biological and medicinal interest. Progress in Medicinal Chemistry 8 61-117. 
Curi R, Newsholme P, Newsholme EA 1988 Metabolism of pyruvate by isolated rat mesenteric lymphocyte, lymphocyte mitochondria and isolated mouse macrophages. Biochemical Journal 250 383-388.

Eastman S, Markholst H, Wilson D, Lernmark A 1991 Leukocytosis at the onset of diabetes in crosses of inbred BB rats. Diabetes Research and Clinical Practice 12 113-123.

Eizirik DL, Mandrup-Poulsen T 2001 A choice of death- the signal-transduction of immune-mediated beta-cell apoptosis. Diabetologia 44 2115-2133.

Elder ME, Maclaren NK 1992 Identification of profound peripheral T lymphocyte immunodeficiencies in the spontaneously diabetic $\mathrm{BB}$ rat. Journal of Immunology 130 1723-1726.

Elsner M, Tiedge M, Guldbakke B, Munday R, Lenzen S 2002 Importance of the GLUT2 glucose transporter for pancreatic beta cell toxicity of alloxan. Diabetologia 45 1542-1549.

Flood RG, Chiang VW 2001 Rate and prediction of infection in children with diabetic ketoacidosis. American Journal of Emergency Medicine 19 270-273.

Holmstrom TH, Eriksson JE 2000 Phosphorylation-based signaling in Fas receptor-mediated apoptosis. Critical Reviews in Immunology $\mathbf{2 0}$ 121-152.

Hsieh SC, Huang MH, Tsai CY, Tsai YY, Tsai ST, Sun KH, Yu HS, Han SH, Yu CL 1997 The expression of genes modulating programmed cell death in normal human polymorphonuclear neutrophils. Biochemical and Biophysical Research Communications 233 700-706.

Innis MA, Gelfand DH 1990 Optimization of PCRs. In PCR Protocols: a Guide to Methods and Applications, edn 1, pp 3-12. Eds MA Innis, DH Gelfand, JJ Sninsky \& TJ White. San Diego: Academic Press.

Jackson R, Rassi N, Crump T, Haynes B, Eisenbarth GS 1981 The $\mathrm{BB}$ diabetic rat: profound $\mathrm{T}$-cell lymphocytopenia. Diabetes $\mathbf{3 0}$ 887-890.

Janssen O, Sanzenbacher R, Kabelitz D 2000 Regulation of activation-induced cell death of mature T-lymphocyte populations. Cell Tissue Research 301 85-99.

Jung CG, Kamyiama T, Agui T 1999 Elevated apoptosis of peripheral $\mathrm{T}$ lymphocytes in diabetic bb rats. Immunology $\mathbf{9 8}$ 590-594.

Kerr JFR, Wyllie AH, Currie AR 1972 Apoptosis: a basic biological phenomenon with wide-ranging implications in tissue kinetics. British Journal of Cancer 25 239-257.

Kidd VJ 1998 Proteolytic activities that mediate apoptosis. Annual Review of Physiology 60 533-573.

Korfel J, Kinalsha I, Rogowski F, Citko A 1990 Cellular immunity in insulin-dependent diabetes mellitus. Polski Tygodnik Lekarski 45 373-375.

Koyama AH, Arakawa T, Adachi A 2000 Characterization of apoptosis induced by sorbitol: a unique system for the detection of antiapoptotic activities of viruses. Microbes and Infections $\mathbf{6}$ 599-606.

Kraine MR, Tisch RM 1999 The role of environmental factors in insulin dependent diabetes mellitus: an unresolved issue. Environmental Health Perspectives 107 777-781.

Kwok S, Higuchi R 1989 Avoiding false positives with PCR. Nature 339 237-238.

Larkin JG, Frier BM, Ireland J 1985 Diabetes mellitus and infection. Postgraduate Medical Journal 61 233-237.

Lavabre-Bertrand T, Bourquard P, Chiesa J, Bertheas MF, Lefort G, Taib J, Lavabre-Bertrand C, Navarro M, Bureau JP 2001. Diabetes insipidus revealing acute myelogenous leukaemia with a high platelet count, monosomy 7 and abnormalities of chromosome 3: a new entity? European Journal of Haematology 66 66-69.

Licastro F, Davis LJ, Morini MC 1993 Lectins and superantigens-membrane interactions of these compounds with T-lymphocytes affect immune responses. International Journal of Biochemistry 25 845-852.
Lien E, Ingalls RR 2002 Toll-like receptors. Critical Care Medicine 30 S1-S11.

Liu B, Andrieu-Abadie N, Levade T, Zhang P, Obeid LM, Hannun YA 1998 Glutathione regulation of neutral sphingomyelinase in tumor necrosis factor-alpha-induced cell death. Journal of Biological Chemistry 273 11313-11320.

Maraschio MA, Kayler LK, Merion RM, Rudich SM, Punch JD, Magee JC, Campbell DA Jr, Arenas JD 2003 Successful surgical salvage of partial pancreatic allograft thrombosis. Transplantation Proceedings 35 1491-1493.

Miller LJ, Marx J 1998 Apoptosis. Science 2811301.

Muller C, Zielinski CC, Kalinowski W, Wolf H, Mannhalter JW, Aschauer-Treiber G, Klosch-Kasparek D, Gaube S, Eibl MM, Schernthaner G 1989 Effects of cyclosporin A upon humoral and cellular immune parameters in insulin-dependent diabetes mellitus type I: a long-term follow-up study. Journal of Endocrinology 121 177-183.

Newton K, Strasser 2001 A cell death control in lymphocytes. Advances in Immunology 76 179-226.

Nicoletti I, Migliorati G, Pagliacci MC, Grignani F, Riccardi C 1991 A rapid and simple method for measuring thymocyte apoptosis by propidium iodide staining and flow cytometry. Journal of Immunological Methods 139 271-279.

Otha H, Sweeney EA, Masamune A, Yatomi Y, Hakamori S, Igarashi Y 1995 Induction of apoptosis by sphingosine in human leukemic HL-60 cells: a possible endogenous modulator of apoptotic DNA fragmentation occurring during phorbol ester-induced differentiation. Cancer 55 691-697.

Otton R, Carvalho CR, Mendonca JR, Curi R 2002a Low proliferation capacity of lymphocytes from alloxan-diabetic rats: involvement of high glucose and tyrosine phosphorylation of Shc and IRS-1. Life Sciences 71 2759-2771.

Otton R, Mendonça JR, Curi R 2002b Diabetes causes marked changes in lymphocyte metabolism. Journal of Endocrinology 174 55-61.

Pallavicini MG, Williami KN 1976 Inhibition of lymphocyte blastogenesis by factor(s) in alloxan-diabetic rat plasma. Diabetes $\mathbf{2 5}$ 614-622.

Porter BO, Malek TR 1999 Prostaglandin E2 inhibits T cell activation-induced apoptosis and Fas-mediated cellular cytotoxicity by blockade of Fas-ligand induction. European Journal of Immunology 29 2360-2365

Rathmel JC, Thompson CB 2002 Pathways of apoptosis in lymphocyte development, homeostasis, and disease. Cell 109 S97-S107.

Rayfield EJ, Ault MJ, Keusch GT, Brothers MJ, Nechemias C, Smith H 1982 Infection and diabetes: the case for glucose control. American Journal of Medicine 72 439-450.

Reinhold D, Ansorge S, Schleicher ED 1996 Elevated glucose levels stimulate transforming growth factor- $\beta 1$ (TGF- $\beta 1$ ), suppress interleukin IL-2, IL-6 and IL-10 production and DNA synthesis in peripheral blood mononuclear cells. Hormone and Metabolic Research 28 267-270.

Sambrook J, Russell DW 2001 Molecular Cloning: a Laboratory Manual, edn 3. Cold Spring Harbor: Cold Spring Harbor Laboratory Press.

Shidham VB, Swami VK 2000 Evaluation of apoptotic leukocytes in peripheral blood smears. Archives of Pathology and Laboratory Medicine 124 1291-1294.

Tough DF, Sprent J 1995 Life span of naive and memory T cells. Stem Cells 13 242-249.

Trauth BC, Klas C, Peters AM, Matzku S, Moller P, Falk W, Debatin KM, Krammer PH 1989 Monoclonal antibody-mediated tumor regression by induction of apoptosis. Science 21 301-305.

Trinder R 1969 Determination of glucose in blood using glucose oxidase with alternative oxygen acceptor. Annals of Clinical Biochemistry 6 24-27.

Vermes I, Haanen C, Reutelingsperger 2000 Flow cytometry of apoptotic cell death. Journal of Immunological Methods 243 167-190. 
Williams GT, Smith CA, Spooncer E, Dexter TM, Taylor DR 1990 Haemopoietic colony stimulating factors promote cell survival by suppressing apoptosis. Nature 343 76-79.

Wyllie AH 1980 Glucocorticoid-induced thymocyte apoptosis is associated with endogenous endonuclease activation. Nature $\mathbf{2 8 4}$ $555-556$.

Wyllie AH, Morris RG, Smith AL, Dunlop D 1984 Chromatin cleavage in apoptosis: association with condensed chromatin morphology and dependence on macromolecular synthesis. Journal of Pathology 142 67-77.

Yale JF, Grose M, Marliss EB 1985 Time course of the lymphopenia in BB rats. Diabetes 34 955-996.

Yokono K, Kawase Y, Nagata M, Hatamori N, Baba S 1989
Suppression of concanavalin A-induced responses in splenic lymphocytes by activated macrophages in the non-obese diabetic mouse. Diabetologia 32 67-73.

Wood SC, Rao TD, Frey AB 1999 Multidose streptozotocin induction of diabetes in $\mathrm{BALB} / \mathrm{cBy}$ mice induces a $\mathrm{T}$ cell proliferation defect in thymocytes which is reversible by interleukin-4. Cellular Immunology 192 1-12.

Zoratti M, Szabo I 1995 The mitochondrial permeability transition. Biochimica et Biophysica Acta 17 139-176.

Received in final form 26 March 2003

Accepted 26 March 2004 